\title{
Incomplete primary hypertrophic osteoarthropathy
}

\author{
Avijeet Prasad, Pratyush Shahi 주, Apoorv Sehgal, \\ Manoj Bhagirathi Mallikarjunaswamy
}

Department of Orthopaedics, University College of Medical Sciences, New Delhi, Delhi, India

\section{Correspondence to} Dr Pratyush Shahi; pratyushshahi@gmail.com

Accepted 27 April 2020

\section{DESCRIPTION}

A 63-year-old man presented with chronic multiple joint pain and swelling. The symptoms had started in adolescence, progressed for about 10-15 years, and then became constant. There was no associated morning stiffness. Symptoms suggesting any chest or abdominal disease were absent. Family history was unremarkable. Physical examination revealed clubbing and bulbous swelling of all fingers and toes, and enlargement of the distal third of both forearms and legs (figure 1). Motion at all joints was mildly restricted. There were no skin changes. Cardiovascular, respiratory, and abdominal examinations were normal. Radiographs showed extensive periosteal changes in the long bones of bilateral forearms and legs, and small bones of hands and feet (figure 2). Chest X-ray, ECG, echocardiogram, and abdominal ultrasonography were normal. All laboratory investigations were normal. A diagnosis of incomplete primary hypertrophic osteoarthropathy (PHOA), which is an extremely rare condition, was made. The patient was prescribed etoricoxib once daily and physical therapy was advised. At 1-year follow-up, the pain had subsided and motion at the joints had improved.

Hypertrophic osteoarthropathy (HOA) is a syndrome of digital clubbing, periosteal new bone formation, and arthritis. It is of two types: (a) secondary HOA associated with a primary underlying disease, and (b) PHOA or idiopathic HOA. PHOA, constituting 3\%-5\% of all hypertrophic osteoarthropathies, is an autosomal dominant or recessive condition thought to be caused due to impaired metabolism of prostaglandin E2 (PGE2). ${ }^{12}$ It is also known as pachydermoperiostosis due to the coarse facial features resulting from thickening and furrowing of skin (pachydermia) and has three clinical variants: (a) complete form, with both pachydermia and
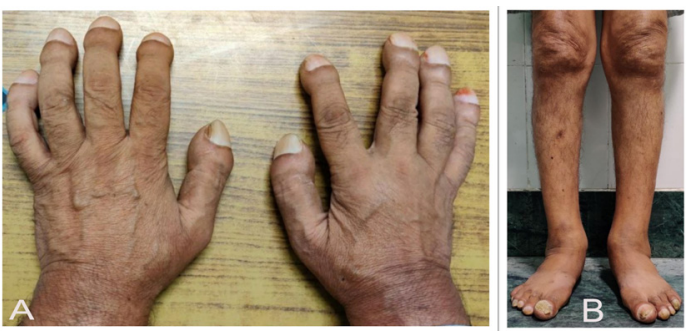

Figure 1 Clubbing and bulbous swelling of all (A) fingers and $(B)$ toes with the widening of the distal part of both legs.

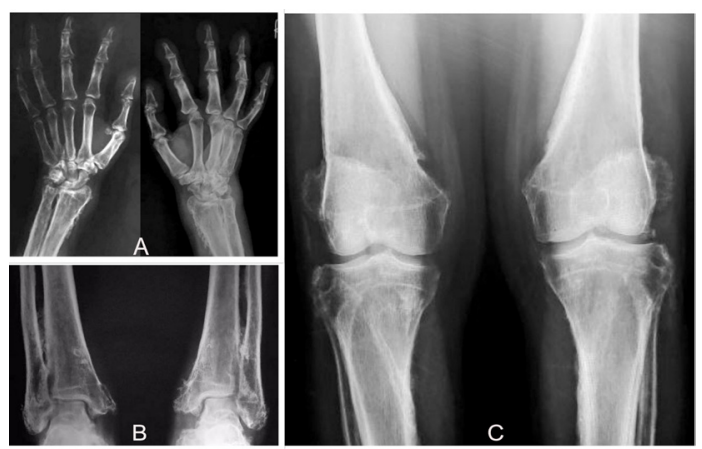

Figure 2 Radiographic assessment. (A) Bilateral hands with a solid, smooth periosteal reaction involving the proximal and middle phalanges, a bulbous increase of soft tissue in the distal phalangeal region and mild terminal acro-osteolysis; (A-C) Shaggy periosteal reaction involving the epiphysis, metaphysis and diaphysis of radius, ulna, femur, tibia and fibula.

periostosis, (b) incomplete form, with periostosis but lacking pachydermia (as seen in our patient) and (c) fruste form, with prominent skin changes but minimal periostosis. ${ }^{3}$ It is important to differentiate between the primary and secondary forms as the latter is associated with cardiopulmonary and abdominal diseases and malignancies. In the primary type, there is generally an insidious onset during adolescence and gradual progression until it becomes stationary, there is familial involvement in about $60 \%$ of the cases, and the periosteal changes involve the diametaphyseal and epiphyseal regions. In contrast, the secondary type has an acute onset and rapid progression along with a waxing-and-waning nature depending on the activity of the aetiologic lesion, is non-hereditary and the epiphyseal region is typically spared. Other similar conditions that can cause confusion include acromegaly, thyroid acropachy, rheumatoid arthritis, multifocal periostitis, osteitis deformans and osteopetrosis. ${ }^{4}$ Non-steroidal anti-inflammatory drugs relieve pain and swelling of joints by blocking PGE2 synthesis. The use of bisphosphonates and glucocorticoids has also been proposed. ${ }^{2}$ Although patients with PHOA have a good prognosis with a normal lifespan, they need to be under regular and long follow-up as complications like ptosis, deafness, kyphosis, osteonecrosis and carpal tunnel syndrome can arise as a result of increased soft tissue bulk and hyperostosis. ${ }^{5}$ 


\section{Patient's perspective}

I started having these symptoms when I was a teenager. My nails started changing shape and my joints swelled. The symptoms increased until I was about 30 years old, then they came to a standstill. Although I had pain, I never really bothered to get proper treatment as I could do most of my activities. When I visited this hospital, the doctors worked me up and explained to me the nature of the disease. My symptoms have subsided to a large extent on analgesics and physical therapy. I am aware that I have to visit the hospital regularly for follow-up.
Contributors AP: idea of the article, literature search and involved in patient care. PS and AS: literature search and wrote the article. MBM: literature search and involved in patient care.

Funding The authors have not declared a specific grant for this research from any funding agency in the public, commercial or not-for-profit sectors.

Competing interests None declared.

Patient consent for publication Obtained.

Provenance and peer review Not commissioned; externally peer reviewed.

\section{ORCID iD}

Pratyush Shahi http://orcid.org/0000-0003-4903-9697

\section{Learning points}

Primary hypertrophic osteoarthropathy (PHOA) is a rare condition and has variable expression.

- It is important to differentiate between the primary and secondary types of hypertrophic osteoarthropathies as the latter is associated with a serious underlying disease.

- Patients with PHOA should be given non-steroidal antiinflammatory drugs for pain and need to be under regular follow-up for monitoring of possible complications.

\section{REFERENCES}

1 Bhate DV, Pizarro AJ, Greenfield GB. Idiopathic hypertrophic osteoarthropathy without Pachyderma. Radiology 1978;129:379-81.

2 Zhang Z, Zhang C, Zhang Z. Primary hypertrophic osteoarthropathy: an update. Front Med 2013:7:60-4.

3 Touraine A, Solente G, Gole L. Un syndrome osteodermopathique: La pachydermie plicaturee avec pachyperiostose Ds extremites. Presse Med 1935;43:1820-4.

4 Berk M. Chronic idiopathic hypertrophic osteoarthropathy; report of a case and review of the literature. N Eng/ J Med 1952;247:123-6.

5 Supradeeptha C, Shandilya SM, Vikram Reddy K, et al. Pachydermoperiostosis - a case report of complete form and literature review. J Clin Orthop Trauma $2014 ; 5: 27-32$

Copyright 2020 BMJ Publishing Group. All rights reserved. For permission to reuse any of this content visit https://www.bmj.com/company/products-services/rights-and-licensing/permissions/

BMJ Case Report Fellows may re-use this article for personal use and teaching without any further permission.

Become a Fellow of BMJ Case Reports today and you can:

- Submit as many cases as you like

- Enjoy fast sympathetic peer review and rapid publication of accepted articles

- Access all the published articles

- Re-use any of the published material for personal use and teaching without further permission

Customer Service

If you have any further queries about your subscription, please contact our customer services team on +44 (0) 2071111105 or via email at support@bmj.com.

Visit casereports.bmj.com for more articles like this and to become a Fellow 